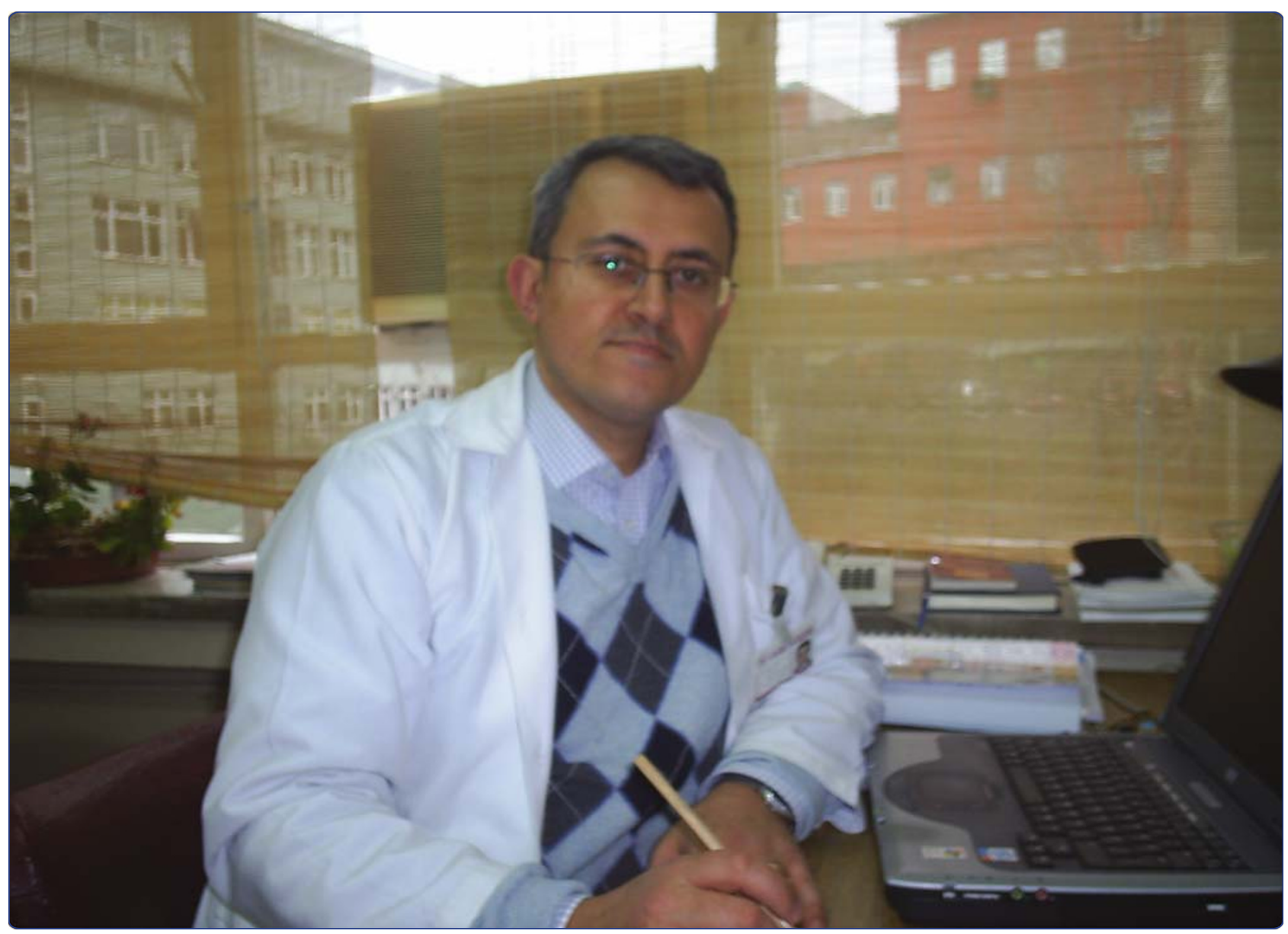

\title{
The role of vitamin $D$ in children with recurrent Tonsillopharyngitis
}

Yildiz et al. 


\title{
The role of vitamin $\mathrm{D}$ in children with recurrent Tonsillopharyngitis
}

\author{
Ismail Yildiz', Emin Unuvar ${ }^{1,5^{*}}$, Umit Zeybek², Bahar Toptas², Canan Cacina², Sadık Toprak ${ }^{3}$, Ayse Kilic \\ and Salih Aydin ${ }^{4}$
}

\begin{abstract}
Background: The exact etiology of recurrent tonsillopharyngitis in children is not clear. Recurrent tonsillitis in children has multifactorial etiology like most of the diseases in childhood. In this study, our aim was to determine the potential role of vitamin $\mathrm{D}$ in recurrent tonsillitis by measuring serum $25-\mathrm{OH}$ vitamin $\mathrm{D}$ levels and determining the vitamin D receptor polymorphism among children with recurrent tonsillitis.

Methods: Eighty-four children with recurrent tonsillitis and seventy-one healthy children aging between 2 and 10 years were enrolled in this study. Serum $25-\mathrm{OH}$ vitamin D level was measured with ELISA and vitamin D receptor gene polymorphism (Apa1, Taq 1, Fok1) was determined by PCR. Serum 25-OH vitamin D level below $50 \mathrm{nmol} / \mathrm{L}$ was accepted as deficiency. The vitamin D receptor gene polymorphism in each group was compared.

Results: The mean age was $5.6 \pm 2.4$ and $6.1 \pm 2.7$ years in study and control group, respectively. The average serum $25-\mathrm{OH}$ vitamin D level was $142.7 \pm 68.1 \mathrm{nmol} / \mathrm{L}$ in study group and $192.3 \pm 56.1 \mathrm{nmol} / \mathrm{L}$ in control group. There was significant difference between the groups $(p<0.01)$. In study group, 4.7\% $(n=4)$ of children had serum $25 \mathrm{OH}$ vitamin D levels below $50 \mathrm{nmol} / \mathrm{L}$. None of the children in control group had serum 25-OH vitamin D level below $50 \mathrm{nmol} / \mathrm{L}$. There was no significant differences in vitamin $\mathrm{D}$ receptor gene polymorphisms between groups.

Conclusion: Serum 25-OH vitamin D levels in recurrent tonsillitis group were lower than those in healthy children. But, there was no difference in the incidence of vitamin D receptor gene polymorphism between the two groups.
\end{abstract}

Keywords: Child, Vitamin D, Infection, Tonsillitis

\section{Introduction}

Tonsillopharyngitis is one of the leading causes of hospital visits during childhood and defined as the acute infection of tonsil and pharynx, characterized by erythema, exudation, ulceration or membrane [1]. It is a major health issue due to its frequent nature, causing labour loss and leading to unreasonable antibiotic use [2]. Besides viruses as the most frequent cause in etiology, the Group A Beta-haemolytic streptococci is the most commonly isolated bacteria [3]. As described by Paradise, at least 7 or more episodes of tonsillopharyngitis in a year or at least 5 episodes of acute tonsillitis in a year for two consequetive years or at least 3 or more episodes of acute tonsillitis in a year for three consequetive years is

\footnotetext{
* Correspondence: eminu@istanbul.edu.tr

'Istanbul Medical Faculty, Department of Pediatrics, Istanbul University, Istanbul, Turkey

${ }^{5}$ Istanbul Tip Fakultesi, Cocuk Klinigi, Capa, Istanbul 34390, Turkey

Full list of author information is available at the end of the article
}

accepted as recurrent tonsillopharyngitis [4]. Although many factors are established for the cause of frequent tonsillopharyngitis, the exact cause has not been identified yet. The environmental conditions, the child's immune system, mucosal characteristics effecting the bacterial biofilm formation on tonsillar tissue and the respond to the infections are of importance [5]. Antibiotics are not effective if bacterial biofilm occurred. Vitamin D has a preventive role for inhibition of bacterial biofilm. Even if the frequency of the disease during the winter is explained by environmental factors such as being indoor during winter, being deprived of sun light is also a point attracting attention. The most important factor provided by the sun is the production of vitamin D. Previous research suggests that vitamin $\mathrm{D}$ has an important role in immune system [6]. Vitamin D has an important role in maintaining of innate immunity. Assignation of vitamin D receptors (VDR) in many tissues has presented new

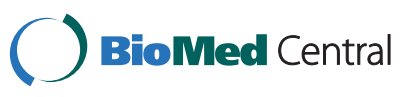


ideas concerning the function of this vitamin. Vitamin $\mathrm{D}$ has numerous effects on different cells types of the immune system such as dendritic cells, B lymphocytes, T lymphocytes, NK cells [7-9]. Some polymorphism characteristics have been described regarding VDR gene affected by vitamin $\mathrm{D}$. The frequently studied ones are Fok I, Bsm, Apa and Taq polymorphisms. Relation has been established between polymorphisms and some diseases $[10,11]$.

In this study, our aim is to determine the role of the polymorphism characteristics of vitamin D and VDR receptors in children diagnosed with recurrent tonsillopharyngitis.

\section{Material and methods Study design}

This clinical retrospective study was carried out among 242 children between 2 and 10 years of age performed in Istanbul University, Istanbul Medical Faculty, Department of Pediatrics, Outpatient Clinic of General Pediatrics between April 2008 and April 2009. During this period, the total number of access to the outpatient clinic was 58933. Four-point seven percent (2780) of these were due to acute tonsillopharyngitis. A hundred and fifteen of these met the eligilbility criteria and included to the study group (115/2780; 4.1\%). A hundred and twenty-seven healthy children followed for different problems by outpatient clinic of the same institution included to the control group. This study was conducted mostly in autumn and winter seasons because of the increased frequency of tonsillopharyngitis during those seasons and seasonal variability of the vitamin D levels. Blood samples were collected from both groups and were studied in the same season. There were 115 cases who met the eligibility criteria of the study. The kit used for this study was designed to run 96 samples for both $25(\mathrm{OH})$ vitamin $\mathrm{D}$ and 1,25- $(\mathrm{OH})$ vitamin $\mathrm{D}$. Twelve out of 96 were used to measure $25(\mathrm{OH})$ vitamin $\mathrm{D}$ and 1,25 $(\mathrm{OH})$ vitamin D levels during the preparation phase of the study. Thus, $25(\mathrm{OH})$ vitamin $\mathrm{D}$ and $1,25(\mathrm{OH})_{2}$ vitamin $\mathrm{D}$ levels were measured for 84 out of 115 subjects (Figure 1).

\section{The eligibility criteria for participants}

\section{Inclusion criteria for the study group are as follows;}

a) Having tonsillopharyngitis more than 7 times a year,

b) Having symptoms of tonsillopharyngitis developed within last 7 days,

c) No conditions requiring to be hospitalized,

d) Given parental consent,

e) No known chronic diseases,

f) Not having any supplementation of vitamin D during the last 3 month.

\section{Tonsillopharyngitis}

Tonsillopharyngitis is diagnosed depending on the physical examination performed by a physician and subjects included to the the study regardless of the etiology, without performing any further microbiologic testing for the distinction of the viral or bacterial causes. The subjects that were diagnosed as tonsillopharyngitis more than 7 times in a year are considered as frequent tonsillopharyngitis. The frequency of tonsillopharyngitis in a year is investigated by reviewing the hospital records and by referring the feedback of parents if the patient is diagnosed with tonsillopharyngitis in a different institution or a prescription for tonsillopharyngitis was given by another physician previously.

Measurement of serum vitamin $D$ level and determination of vitamin D receptor (VDR) gene polymorphism

In this study serum $25(\mathrm{OH})$ and $1,25-(\mathrm{OH})$ vitamin $\mathrm{D}$ levels were measured by sandwich Enzyme Linked Immunosorbent Assay (ELISA) method. DNA of the subjects was isolated from the blood samples obtained and VDR's Apa, Taq , Fok I polymorphisms were determined through primer series $[12,13]$.

\section{Interpretation of serum vitamin D levels}

Serum $25(\mathrm{OH})$ vitamin D level was interpreted as insufficient, sufficient, excess and intoxication if the blood level was between $50-80 \mathrm{nmol} / \mathrm{L}, 80-250 \mathrm{nmol} / \mathrm{L}, 250-$ $325 \mathrm{nmol} / \mathrm{L}$ and above $325 \mathrm{nmol} / \mathrm{L}$. Serum $25(\mathrm{OH})$ vitamin D level below $50 \mathrm{nmol} / \mathrm{L}$ was accepted as apperent deficiency (14) while the normal range of Serum 1,25$(\mathrm{OH})_{2}$ vitamin D was considered as $16-65 \mathrm{pg} / \mathrm{ml}$ [14].

\section{Factors affecting serum vitamin D level}

Daily exposure to sunlight, gender, age, weight,, and the amount of time spent with outdoor activities and at seaside were investigated in both groups.

\section{Ethical committee approval and support}

Istanbul University, Istanbul Shool of Medicine ethical committee approval was taken in January 2008 with the file numbered 2008/35 before the study was performed. This study was supported by Istanbul University Scientific Research Projects (Project No: 2006).

\section{Statistical analysis}

In the evaluation of the qualitative and quantitative parameters, Student's t-test, Chi-Square, Fisher's exact chi-square, Pearson correlation analysis and logistic regression tests were utilized. Statistical analyses were made by SPSS 10.0 software program. The threshold for significance was $\mathrm{p}<0.05$. 


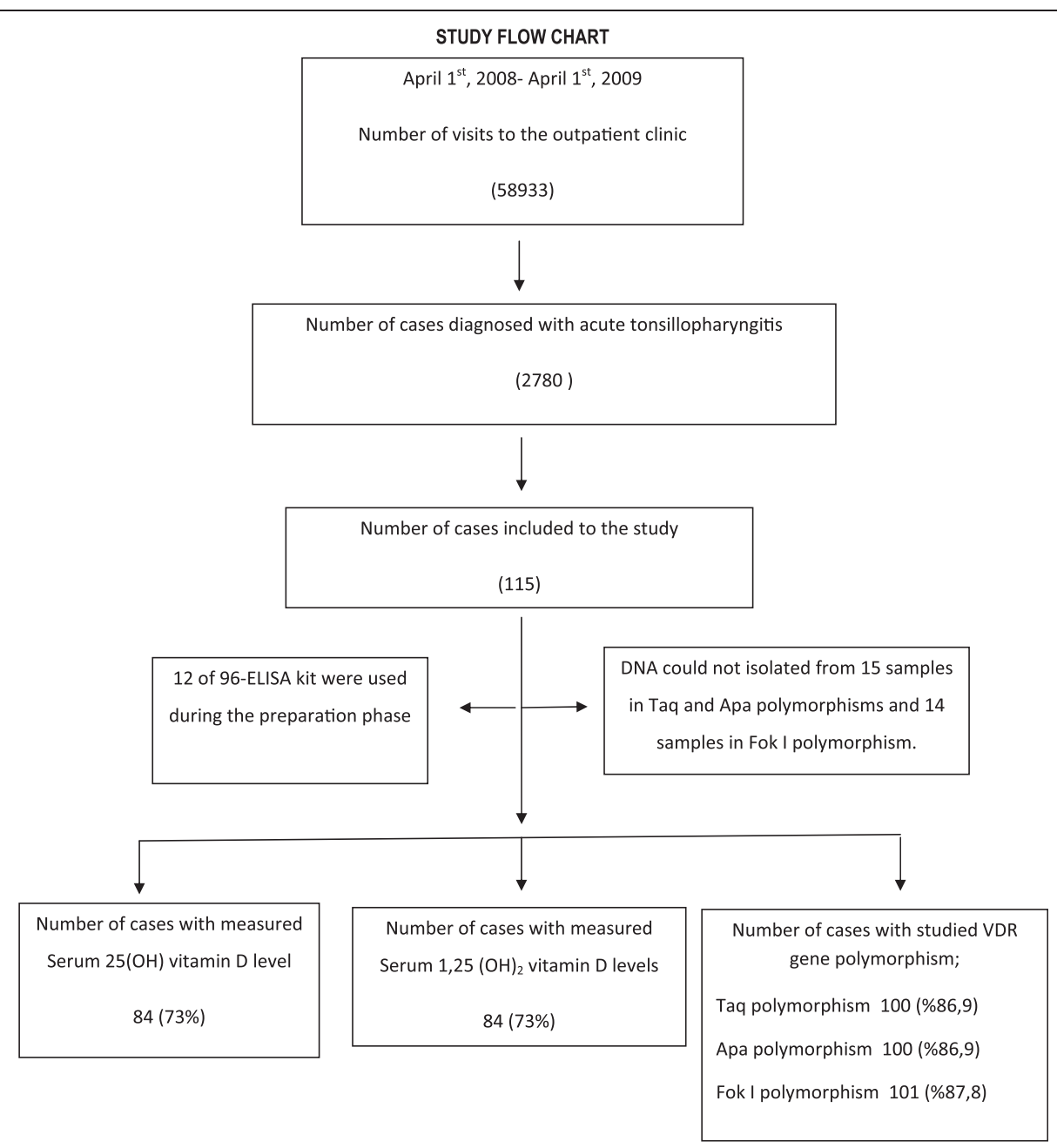

Figure 1 Flow chart of the study.

\section{Results}

The characteristics of the groups were as follows: $39.1 \%$ of study group (n: 45 ) and $44.9 \%$ of control group (n: 57 ) were girls $(\mathrm{p}=0.36)$. The average age of study group was $5.6 \pm 2.4$ years and control group was $6.1 \pm 2.7$ years $(\mathrm{p}=0.13)$. The average weight of study group was $21.3 \pm 8.0 \mathrm{~kg}$ and of control group was $21.8 \pm 8.7 \mathrm{~kg}$ $(\mathrm{p}=0.72)$. The average height of study group was $113.8 \pm 16.2 \mathrm{~cm}$ and of control group was $112.8 \pm 19.3 \mathrm{~cm}$ $(\mathrm{p}=0.74$; Table 1$)$. The average annual frequency of tonsillopharyngitis of study group was $15.3 \pm 4.7$ times and control group was $2.5 \pm 0.9$ times $(\mathrm{p}<0.01)$.

In study group, $25(\mathrm{OH})$ vitamin D level was studied in 84 of 115 cases $(84 / 115 ; 73 \%)$. The average serum 25 $(\mathrm{OH})$ vitamin $\mathrm{D}$ level was $142.7 \pm 68.1 \mathrm{nmol} / \mathrm{L}$. The lowest serum $25(\mathrm{OH})$ vitamin D level was measured as $18 \mathrm{nmol} / \mathrm{L}$ and the highest level was $331 \mathrm{nmol} / \mathrm{L}$. Serum $25(\mathrm{OH})$ vitamin D level of 4 cases $(4 / 84 ; 4.7 \%)$ was below $50 \mathrm{nmol} / \mathrm{L}$, which was considered as the cut off for vitamin $\mathrm{D}$ deficiency. The values of these 4 cases were measured as $18,24,39,49 \mathrm{nmol} / \mathrm{L}$. In one case, serum $25(\mathrm{OH})$ vitamin $\mathrm{D}$ level was found above $325 \mathrm{nmol} / \mathrm{L}$ considered as above the intoxication limit. In control group, 25(OH) vitamin D level was studied in 71 of 127 cases $(71 / 127 ; 55.9 \%)$. The average serum 25 $(\mathrm{OH})$ vitamin $\mathrm{D}$ level was $192.3 \pm 56.1 \mathrm{nmol} / \mathrm{L}$. The

Table 1 Main characteristics of the cases

\begin{tabular}{|c|c|c|c|}
\hline & \multicolumn{2}{|c|}{ GROUPS } & \multirow[t]{3}{*}{$P$ value } \\
\hline & Study Group & Control Group & \\
\hline & $(n: 115)$ & $(n: 127)$ & \\
\hline Gender Girl; n (\%) & 45 (39.1) & $57(44.9)$ & 0.36 \\
\hline Age (years) & $5.6 \pm 2.4$ & $6.1 \pm 2.7$ & 0.13 \\
\hline Weight (kg) & $21.3 \pm 8.0$ & $21.8 \pm 8.7$ & 0.72 \\
\hline Height (cm) & $113.8 \pm 16.2$ & $112.8 \pm 19.3$ & 0.74 \\
\hline $\begin{array}{l}\text { Annual tonsillopharyngitis } \\
\text { frequency }\end{array}$ & $15.3 \pm 4.7$ & $2.5 \pm 0.9$ & $<0.01$ \\
\hline
\end{tabular}

Study group consisted of the cases having frequent tonsillopharyngitis and control group consisted of healthy cases. 
Table 2 Serum levels of $25-\mathrm{OH}$ vitamin D levels were measured in 84 patients in study group and 71 patients in control group

\begin{tabular}{lccc}
\hline & $\begin{array}{c}\text { Study } \\
\text { Group }\end{array}$ & $\begin{array}{c}\text { Control } \\
\text { Group }\end{array}$ & P value \\
\hline $\begin{array}{l}\text { Serum 25(OH) vitamin D level } \\
\text { (nmol/L) }\end{array}$ & $142.7 \pm 68.1$ & $192.3 \pm 56.1$ & $<0.01$ \\
$\begin{array}{l}\text { Serum 1,25-(OH) } \\
\begin{array}{l}\text { D level }(\mathrm{pg} / \mathrm{mL}) \\
\text { Number of patients with serum }\end{array}\end{array}$ & $35.8 \pm 16.4$ & $28.4 \pm 14.1$ & $<0.01$ \\
$\begin{array}{l}25-\mathrm{OH} \text { vitamin D level } \\
\text { below }<50 \mathrm{nmol} / \mathrm{L}\end{array}$ & & & \\
\hline
\end{tabular}

Serum $1,25(\mathrm{OH})_{2}$ vitamin $\mathrm{D}$ was measured in 84 patients in study group and 79 patients in control group.

lowest level was measured as $81 \mathrm{nmol} / \mathrm{L}$ and the highest level was $303.7 \mathrm{nmol} / \mathrm{L}$. No cases were found at deficiency or intoxication limit in control group. The average serum $25(\mathrm{OH})$ vitamin D level of study group was significantly lower than that of control group $(\mathrm{p}<0.01)$ (Table 2 and Figure 2).

In study group, serum $1,25-(\mathrm{OH})_{2}$ vitamin $\mathrm{D}$ level was also studied in 84 of 115 cases (73\%). The average serum $1,25-(\mathrm{OH})_{2}$ vitamin D level was $35.8 \pm 16.4 \mathrm{pg} / \mathrm{ml}$. The lowest level was measured as $12.2 \mathrm{pg} / \mathrm{ml}$ and the highest level was $81.5 \mathrm{pg} / \mathrm{ml}$. In 3 cases, $1,25-(\mathrm{OH})_{2}$ vitamin D level was below normal limit (Values: 12.2, 13.5, $13.7 \mathrm{pg} / \mathrm{ml}$ ). In 6 cases, $1,25-(\mathrm{OH})_{2}$ vitamin D level was above normal limit (Values: 66.2, 78.8, 80.1, 80.4, 80.5, $81.5 \mathrm{pg} / \mathrm{ml}$ ). In control group, serum $1,25-(\mathrm{OH})_{2}$ vitamin D level was studied in 79 of 127 cases (62.2\%). The average serum $1,25-(\mathrm{OH})_{2}$ vitamin D level was $28.6 \pm 14.1 \mathrm{pg} / \mathrm{ml}$. The lowest level was measured as $7.4 \mathrm{pg} / \mathrm{ml}$ and the highest level was $66.2 \mathrm{pg} / \mathrm{ml}$. In 10 cases from control group, $1,25-(\mathrm{OH})_{2}$ vitamin $\mathrm{D}$ level was below normal limit
(Values: 7.4, 7.9, 8.1, 8.2, 10.4, 10.8, 10.9, 11.5, 13, $14.3 \mathrm{pg} / \mathrm{ml})$. In one case, $1,25-(\mathrm{OH})_{2}$ vitamin $\mathrm{D}$ level was above normal limit $(66.2 \mathrm{pg} / \mathrm{ml})$. The average $1,25-(\mathrm{OH})_{2}$ vitamin D level of study group was significantly higher than that of control group $(\mathrm{p}<0.01)$.

Regarding Taq, Apa and Fok I polymorphisms in VDR receptor gene, no statistically significant difference was found between study and control groups ( $\mathrm{p}$ values: 0.99, 0.14, 0.55, respectively, Table 3).

In multivariate analysis, the most efficient parameters on annual disease frequency were serum $25(\mathrm{OH})$ vitamin $\mathrm{D}$ and $1,25(\mathrm{OH})_{2}$ vitamin D levels; the annual disease frequency increases with "Ff" polymorphism, whereas decreases with "ff" polymorphism.

\section{Discussion}

The existence of VDRs in immune system cells and different modulatory effects upon the stimulation of these receptors have brought forward the relation of vitamin $\mathrm{D}$ and immune system [5,6]. The best parameter for the evaluation of vitamin D level and vitamin D pool in the body is serum $25(\mathrm{OH})$ vitamin D levels, whose half life of is about 20 days [13-15]. Since the half life of the biologically active form, $1,25-(\mathrm{OH})_{2}$ vitamin $\mathrm{D}$ is as short as 3 to 6 hours and the circulating blood level is very low compared to $25(\mathrm{OH})$ vitamin $\mathrm{D}$, its use is not preferred for the evaluation of serum vitamin D levels [16]. In our research, we studied the level of $25(\mathrm{OH})$ vitamin D which gives information on body vitamin $\mathrm{D}$ storage and also the level of biologically active form, $1,25-(\mathrm{OH})_{2}$ vitamin $\mathrm{D}$ together. Due to the ease of the technique, serum $25(\mathrm{OH})$ vitamin D and $1,25-(\mathrm{OH})_{2}$ vitamin D levels were measured by ELISA method. Vitamin D is effective on all other systems apart from its important role in bone

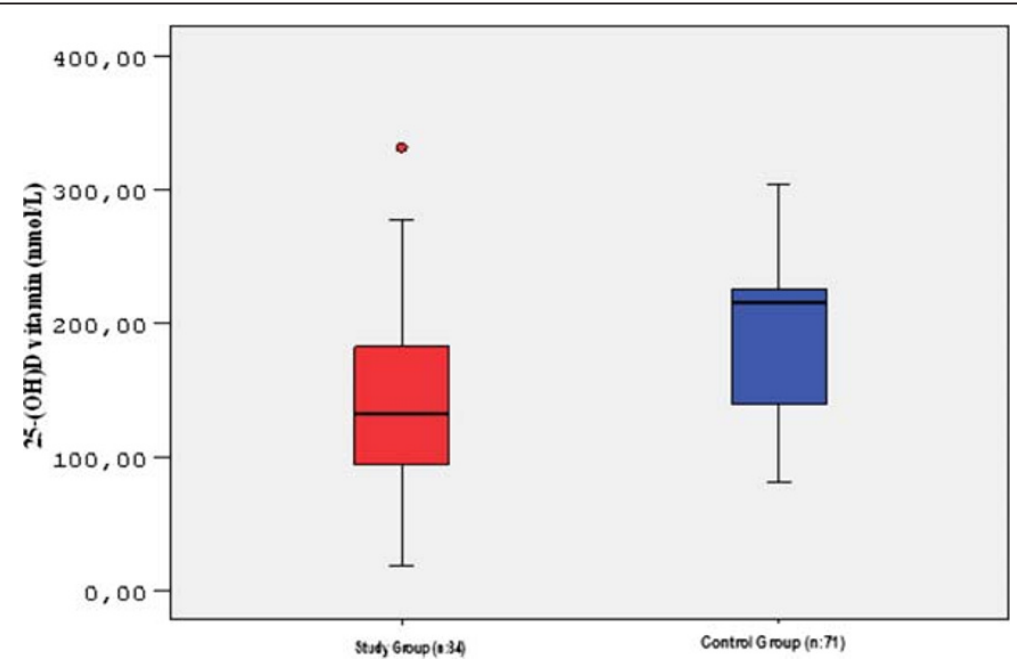

Figure 2 Serum $25-(\mathrm{OH})$ vitamin D levels. Serum 25-OH vitamin D levels were measured in 84 cases in study group and in 71 cases in control group. 
Table 3 Vitamin D receptor gene polymorphism

\begin{tabular}{|c|c|c|c|c|}
\hline \multirow[t]{2}{*}{ VDR } & \multirow{2}{*}{$\begin{array}{c}\text { Gene } \\
\text { Polymorphisms }\end{array}$} & \multirow{2}{*}{$\frac{\text { Study Group }}{(\mathrm{n}: 100)(\mathrm{n} ;(\%))}$} & \multirow{2}{*}{$\frac{\text { Control Group }}{(\mathrm{n}: 104)(\mathrm{n} ;(\%))}$} & \multirow[t]{2}{*}{$P$ value } \\
\hline & & & & \\
\hline \multirow[t]{3}{*}{ Taq } & $\pi$ & $49(49)$ & $50(48.5)$ & 0.99 \\
\hline & $\mathrm{Tt}$ & $40(40)$ & $42(40.8)$ & \\
\hline & $\mathrm{tt}$ & $11(11)$ & $11(10.7)$ & \\
\hline \multirow[t]{3}{*}{ Apa } & AA & 39 (39) & $43(42.6)$ & 0.14 \\
\hline & $\mathrm{Aa}$ & $53(53)$ & $58(57.4)$ & \\
\hline & aа & $8(8)$ & $0(0)$ & \\
\hline \multirow[t]{3}{*}{ Fok I } & $\mathrm{FF}$ & $46(45.5)$ & $54(53.5)$ & 0.55 \\
\hline & $\mathrm{Ff}$ & $52(51.5)$ & $41(40.6)$ & \\
\hline & ff & $3(3)$ & $6(5.9)$ & \\
\hline
\end{tabular}

VDR gene polymorphism was analyzed in 100 cases for study group and in 104 cases for control group.

and mineral (calcium, phosphorus) metabolisms. Since our study has been carried out on children having frequent tonsillopharyngitis that is not associated with bone-mineral system; serum calcium, phosphorous, alkaline phosphatase and parathormone levels were not measured.

The human VDR is polymorphic [16]. Recently, a relation was established between VDR gene polymorphisms and predisposition to some diseases [10]. Presence of the $t$ allele of the TaqI VDR receptor polymorphism is associated with increased anti-infective action against tuberculosis $[17,18]$. In contrast, presence of the $f$ allele of the FokI VDR polymorphism is associated with reduction in anti-infective action against tuberculosis $[17,19]$. The significance of VDR polymorphisms on vitamin $\mathrm{D}$ production and activity is a developing field. We tried to establish a relation between VDR gene polymorphism and frequent tonsillopharyngitis in children. In our study, we observed that annual disease frequency increases in the patients with " $\mathrm{Ff}$ " polymorphism, whereas it decreases in those ones with "ff" polymorphisms. Our findings were in contrast with the literature demonstrating negative correlation between VDR ff allele polymorphism and recurrent tonsillopharyngitis [20].

Although the average serum 25- $(\mathrm{OH})$ vitamin D levels were in the normal range in both groups, it was significantly lower in the children with frequent tonsillopharyngitis $(\mathrm{p}<0.01)$. In our study, we tried to determine the serum $25-(\mathrm{OH})$ vitamin D level that effectively prevents tonsillopharyngitis. However, because of the limited number of cases in our study, we were not able to make this assessment. But some preliminary data showed that serum 25-OH vitamin D levels are lower in patients with recurrent tonsillopharyngitis [21]. Two randomized controlled trails reported that, vitamin $\mathrm{D}$ supplementation is effective for prevention of upper respiratory tract infections [22,23]. To determine the minimal serum vitamin $\mathrm{D}$ level necessary to protect against upper respiratory tract infections, more cohort studies with a larger number of cases are needed. The difference of serum $1,25-(\mathrm{OH})_{2}$ vitamin D levels between the groups may be because of the short half-life of serum $1,25-(\mathrm{OH})_{2}$ vitamin $\mathrm{D}$ and the difference in study timing of the samples at the laboratory.

Aydin and colleagues [24] conducted a prospective research. Aydin and colleagues checked the serum 25$(\mathrm{OH})$ vitamin D levels in tonsillectomy patients with recurrent tonsillitis, whilst our group checked the serum 25- $(\mathrm{OH})$ vitamin D and $1.25(\mathrm{OH}) 2$ vitamin D levels of children with frequent tonsillopharyngitis. Whilst both studies into serum 25- $(\mathrm{OH})$ vitamin D levels were within the normal range, Aydin and colleagues found no statistical differences with the control group. Our study did show a statistical difference.

In our study, the children who had recurrent tonsillopharyngitis during the one-year period were determined and their serum vitamin D levels were studied. Since vitamin $\mathrm{D}$ is affected by external factors and displays seasonal differences in particular, studying serum vitamin D levels by means of taking serum samples in both summer and winter would have been ideal. Evaluating the nutritional characteristics of the children would make the study more reliable.

In conclusion, based on this study, low serum vitamin D level can be a risk factor for recurrent tonsillopharyngitis. In children having recurrent tonsillopharyngitis, serum $25(\mathrm{OH})$ vitamin levels were lower than those of healthy children. But, there was no difference in vitamin D receptor gene polymorphism. In the future, giving vitamin $\mathrm{D}$ support to the children with recurrent tonsillopharyngitis, then measuring their serum vitamin D levels and observing the decrease in annual disease frequency after the supportive treatment would exactly explain the relation between vitamin $\mathrm{D}$ and having recurrent tonsillopharyngitis.

\section{Competing interests}

The authors declare that they have no competing interests.

\section{Authors' contributions}

IY, EU, AK and SA carried out the clinic studies. UZ, BT and CC participated in measurements of the levels of vitamin D. ST carried out the statistical analysis. All authors participated to drafted the manuscript. All authors read and approved the final manuscript.

\section{Author details}

Istanbul Medical Faculty, Department of Pediatrics, Istanbul University, Istanbul, Turkey. ${ }^{2}$ Institute of Experimental Medical Researches, Department of Molecular Medicine, Istanbul University, Istanbul, Turkey. ${ }^{3}$ Medical Faculty, Department of Forensics Medicine, Zonguldak Karaelmas University, Zonguldak, Turkey. ${ }^{4}$ Istanbul Medical Faculty, Department of ENT Clinic, Istanbul University, Istanbul, Turkey. ${ }^{5}$ stanbul Tıp Fakultesi, Cocuk Klinigi, Capa, Istanbul 34390, Turkey.

Received: 26 September 2011 Accepted: 7 May 2012

Published: 8 June 2012 


\section{References}

1. Armstrong GL, Pinner RW: Outpatient visits for infectious diseases in the United States, 1980 through 1996. Arch Intern Med 1999, 159:2531-2536.

2. Makela MJ, Puhakka T, Ruuskanen O, Leinonen M, Saikku P, Kimpimaki M, Blomqvist S, Hyypia T, Arstila P: Viruses and bacteria in the etiology of the common cold. J Clin Microbiol 1998, 36:539-542.

3. Alan L, Bisno MD: Acute pharyngitis: etiology and diagnosis. Pediatrics 1996, 97:949-954.

4. Paradise IL, Bluestone CD, Colborn DK, Bernard BS, Rockette HE, Kurs-Lasky $\mathrm{M}$ : Tonsillectomy and adenotonsillectomy for recurrent throat infection in moderately affected children. Pediatrics 2002, 110:7-15.

5. Kania RE, Lamers GE, Vonk MJ, Huy PT, Hiemstra PS, Bloemberg GV, Grote JJ: Demonstration of bacterial cells and glycocalyx in biofilms on human tonsils. Arch Otolaryngol Head Neck Surg 2007, 133:115-121.

6. Bartley J: Vitamin D, innate immunity and upper respiratory tract infection. J Laryngol Otol 2010, 124:465-469.

7. Deluca HF, Cantorna MT: Vitamin D: its role and uses in immunology. FASEB J 2001, 15:2579-2585.

8. Van Etten E, Mathieu C: Immunregulation by1,25-dihydroxyvitamin D3: basic concepts. J Steroid Biochem Mol Biol 2005, 97:93-101.

9. Zmuda JM, Cauley JA, Ferrell RE: Molecular epidemiology of vitamin D receptor gene variants. Epidemiol Rev 2000, 22:203-217.

10. Valdivielso JM, Fernandez E: Vitamin D receptor polymorphisms and diseases. Clin Chim Acta 2006, 371:1-12.

11. Bell NH, Morrison NA, Nguyen TV, Eisman J, Hollis BW: Apa I polymorphisms of the vitamin $\mathrm{D}$ receptor predict bone density of the lumbar spine and not racial difference in bone density in young men. J lab Clin Med 2001, 137:133-140

12. Vogel A, Strassburg CP, Manns MP: Genetic association of vitamin D receptor polymorphisms with primary biliary chirrhosis and autoimmune hepatitis. Hepatology 2002, 35:126-131.

13. Grant WB, Holick MF: Benefits and requirements of vitamin D for optimal health: a review. Altern Med Rev 2005, 10:94-111.

14. Vieth $R$ : Vitamin D supplementation, 25-hydroxyvitamin D concentrations, and safety. Am J Clin Nutr 1999, 69:842-856

15. Adams JS, Hollis BW: Vitamin D: Synthesis, metabolism and clinical measurement. In Disorders of bone and mineral metabolism. In Disorders of bone and mineral metabolism. 2nd edition. Edited by Coe FL, Favus MJ. Philadelphia: Lippincott Williams \& Wilkins; 2002:157-174.

16. Uitterlinden A, Fang Y, Van Meurs J, Pols H, Van Leeuwen J: Genetics and biology of vitamin D receptor polymorphisms. Gene 2004, 338:143-156.

17. Selvaraj P, Chandra G, Jawahar M, Rani M, Rajeshwari D, Narayanan P: Regulatory role of vitamin D receptor gene variants of Bsm I, Apa I, Taq I, and Fok I polymorphisms on macrophage phagocytosis and pymphoproliferative response to mycobacterium tuberculosis antigen in pulmonary tuberculosis. J Clin Immunol 2004, 24:423-432.

18. Roth D, Soto G, Arenas F, Bautista C, Ortiz J, Rodriquez R, et al: Association between vitamin $D$ receptor gene polymorphisms and response to treatment of pulmonary tuberculosis. J Infect Dis 2004, 190:920-927.

19. McGrath JJ, Saha S, Burne THJ, Eyles DW: A systematic review of the association between common single nucleotide polymorphisms and 25-hydroxyvitamin D concentrations. J Steroid Biochemistry and Molecular Biology 2010, 121:471-477.

20. Roth $\mathrm{DE}$, Jones $\mathrm{AB}$, Prosser $\mathrm{C}$, Robinson JL, Vohra S: Vitamin $\mathrm{D}$ receptor polymorphisms and the risk of acute lower respiratory tract infection in early childhood. J Infect Dis 2008, 197:676-680.

21. Reid D, Morton R, Salkeld L, Bartley J: Vitamin D and tonsil disease- Preliminary observation. Int J Ped Otorhinolaryngol 2011 75:261-264

22. Laaski I, Ruohola P, Mattilia V, Auvinen A, Vlikanin T, Pihlajamaki H: Vitamin $D$ supplementation for the prevention of acute respiratory tract infections.A randomized double-blinded trial amongst young Finnish men. J Infect Dis 2010, 202:809-814.
23. Li-Ng M, Aloia JF, Polleck S, Cunha BA, Mikhail M, Yeh J, et al: A randomized controlled trial of vitamin D3 supplementation for the prevention of symptomatic upper respiratory tract infections. Epidemiol Infect 2002, 137:1396-1404.

24. Aydın S, Aslan I, Yıldız I, Ağaçhan B, Toptaş B, Toprak S, Değer K, Oktay MF, Unüvar E: Vitamin D levels in children with recurrent tonsillitis. Int Pediatr Otorhinolaryngol 2011, 75:364-367.

doi:10.1186/1824-7288-38-25

Cite this article as: Yildiz et al:: The role of vitamin D in children with recurrent Tonsillopharyngitis. Italian Journal of Pediatrics 2012 38:25.

\section{Submit your next manuscript to BioMed Central and take full advantage of:}

- Convenient online submission

- Thorough peer review

- No space constraints or color figure charges

- Immediate publication on acceptance

- Inclusion in PubMed, CAS, Scopus and Google Scholar

- Research which is freely available for redistribution

Submit your manuscript at www.biomedcentral.com/submit
Biomed Central 